\title{
Characteristics of entrepreneurs and public support for NTBFs
}

\author{
Felipe Rojas and Elena Huergo \\ GRIPICO-Universidad Complutense de Madrid*
}

February 2015

\begin{abstract}
This paper studies the role of the characteristics of entrepreneurs as determinants of public financial support for New Technology Based Firms (NTBFs). Using a single database about the profile of Spanish technology entrepreneurs from 2001 to 2009, we analyze the relationship between NTBF participation in the NEOTEC program run by the main Spanish public agency for R\&D and four dimensions of the entrepreneurial team: its human capital, its links to the public system of R\&D, its motivation at the time the company was created and the extent of its planning to initiate the business activity. Our results show that NTBFs founded by entrepreneurs who have less experience in management, have planned less, are more oriented toward growth and have closer ties to the public system of R\&D are more likely to participate in the public aid program.
\end{abstract}

\section{Key words: New Technology Based Firms, impact assessment, innovation policy}

\section{J.E.L. Codes: M13, H81, 038}

\footnotetext{
*Address for correspondence: GRIPICO (Group for Research in Productivity, Innovation and Competition). Dpto. Fundamentos del Análisis Económico I. Facultad de CC. Económicas y Empresariales. Universidad Complutense de Madrid. Campus de Somosaguas. 28223 Madrid. España. E-mails: ferojas@ucm.es; ehuergo@ccee.ucm.es
}

We thank Marco Vivarelli and an anonymous referee for their helpful comments. This research has been partially financed by the European Union Framework Programme 7 (Project SIMPATIC, GA No. 290597) and by the Spanish Ministry of Economy and Competitiveness (project ECO2014-52051-R). Elena Huergo is also grateful to the CDTI for the data provided to carry out this research. Comments by the participants in the 3rd edition of the International Conference GCW have particularly improved the final draft of this paper. 


\section{Introduction}

There is no conclusive agreement on the contribution of small and medium-sized enterprises (SMEs) to growth, as this group of firms includes both highly innovative New Technology Based Firms (NTBFs) and traditional, financially constrained SMEs (Ortega-Argilés et al. 2009). However, most of the evidence coincides in pointing out that, among SMEs, the sub-set of highly innovative new companies grows faster and performs better than other firms (Storey and Tether, 1998; Almus and Nerlinger, 1999; Acs and Audretsch, 2003; Santarelli and Vivarelli 2007; Czarnitzki and Delanote, 2013). In fact, the lower presence of young leading innovators in Europe compared with the U.S., especially in high-tech sectors, is a key explanation of the weakness of R\&D investment by the European business sector (Cincera and Veugelers, 2013, 2014).

Following Fontes and Coombs (2001), the main contribution of NTBFs to the strengthening of technological capabilities in 'intermediate economies' ${ }^{1}$ would reside in their technological dynamism. In particular, three functions carried out by NTBFs can be highlighted: (i) the transfer of knowledge and technology from local academic research to the market; (ii) the acquisition of technological knowledge that is developed outside of the country and is combined with local knowledge and capabilities, giving rise to national competences; and (iii) the densification of technological and industrial networks in some fields where NTBFs act as technological intermediaries.

Along these lines, Licht and Nerlinger (1998) emphasize that in Germany, NTBFs have generated indirect qualitative incentives for technological change through the transfer and diffusion of technology. Bade and Nerlinger (2000) stress the role of German NTBFs as promoters of technological change and innovation in the 1980s. For Portugal, Fontes and Coombs (2001) demonstrate that NTBFs have contributed to strengthening technological capacity in the sectors they specialize in and improve the availability of new technological products. Lastly, Stam and Wennberg (2009), in their study on Holland, conclude that innovative start-ups might be an important focus for innovation policy, since they offer new

\footnotetext{
${ }^{1}$ This term refers to countries that already have a substantial scientific base, although their industrial structure still presents a number of weaknesses (Hinard de Pádua et al., 2002).
} 
nodes in innovation networks, which are added to the density and diversity of innovation system networks.

Because of these externalities of NTBFs, researchers have tried to identify the factors that make it difficult to create and develop them. Some of these factors are the characteristics of their founders (Almus and Nerlinger, 1999; Colombo and Grilli, 2005; Ganotakis, 2012), the technological environment the company works in (Vivarelli, 2013), and especially their sources of financing (Revest and Sapio, 2012). As such, some authors note that among founders there is usually little competence in company management tasks or, in general, few skills in non-technological areas (Fontes and Coombs, 2001). With regard to financial factors, small innovative companies face high capital costs (Hall, 2002), which are only partially mitigated by the presence of venture capital (Hall and Lerner, 2010).

Considering these difficulties for the development of NTBFs, public policy-makers have developed a set of support instruments for this type of company, which is consistent with the idea that a general-purpose erga omnes policy for SMEs would be less appropriate than a targeted RTD policy addressed to particular sub-groups of SMEs (Ortega-Argilés et al., 2009). Among these instruments we can highlight: (i) the creation of technology parks (Löfsten and Lindelöf, 2002; Siegel et al., 2003; Phan et al., 2005; Fukugawa, 2006); (ii) the supply of doctorates in science and technology and services of technological consulting about NTBFs (Storey and Tether, 1998b); (iii) the promoting of relations between NTBFs and universities or research institutes, through company incubators (Mian, 1996; Aernoudt, 2004; Soetanto and Jack, 2013), technological transfer offices and public research institutes (Lockett et al., 2005; Colombo et al., 2009; Morandi, 2013) and (iv) financial support of NTBFs (Kösters, 2010; Colombo et al., 2011; Cantner and Kösters, 2012). For the specific case of financial support, public policy includes subsidies as well as soft loans and public venture capital.

Surprisingly, there are few studies which analyze the factors that determine the participation of NTBFs in public support programmes (Grilli and Murtinu, 2012). Two exceptions are the studies by Kösters (2010) and Cantner and Kösters (2012). For Kösters (2010), the novelty of the idea of business, the founders' ambition for the company to grow and the variables related to the human capital of these founders are not important for the 
allocation of subsidies in the eastern German state of Turingia, but the company's start-up capital is. That permits her to conclude that public policy is not contributing to alleviating the imperfections of the capital market. However, in the further study with data for the same region but considering new explanatory factors, Cantner and Köster (2012) find that the novelty of the idea and being an academic spin-off increase the chances of receiving public support.

The objective of this paper is to contribute to this debate by analyzing the role of entrepreneurial characteristics as determinants of NTBF participation in public systems of financial support designed especially for them. In particular, we provide evidence of Spanish NTBF participation within the framework of the NEOTEC program, created by the Centro para el Desarrollo Tecnológico Industrial (CDTI), which is the main Spanish public agency with regard to $R \& D .^{2}$

The data for this research come from a survey conducted by the CDTI in 2009 and 2010. The goal of this survey was to characterize the profile of the technological entrepreneur. This information has been completed with information from Sistema de Análisis de Balances Ibéricos (SABI), which includes data on the sector of activity, geographic location and the year the company was founded.

To identify the determinants of participation in the NEOTEC program, we use a Probit model which includes different features of entrepreneurs and the NTBF. In particular, four different types of characteristics are considered: the human capital of the entrepreneurial team, the links of the NTBF and its founders with the public system of R\&D, the motivations of the entrepreneurs at the time the company is created and the degree of previous planning. The results show that all these dimensions are important in explaining the probability of participating in the public aid program.

The rest of the paper is structured as follows. In Section II, the financial needs of NTBFs are briefly described. In Section III, the hypotheses with regard to founders'

\footnotetext{
${ }^{2}$ Although it has developed and matured in the last 20 years, there is still a deficit of venture capital for investments that include totals between 0.5 and 1 million euros (Del-Palacio et al. 2012). The public contribution of the CDTI and the Empresa Nacional de Innovación, S.A. (Enisa) has been important since the year 2005, intensifying in the years 2010-2012 in direct contributions as well as through public resources in private venture capital (webcapitalriesgo.com). As is explained in detail in Section IV, the NEOTEC program is one of the CDTI's basic resources in support of NTBFs.
} 
characteristics and their business plans that could determine participation in the public aid program are specified. In Section IV, the NEOTEC program and the data used are described. Afterwards, in Section V, the empirical model is presented and the results are discussed. Finally, Section VI presents the main conclusions.

\section{The financing of NTBFs}

Economics literature explains the financing deficit of innovating companies mainly by the presence of information asymmetry and moral hazard, which provoke a higher cost of financing research, development and innovation (R\&D\&I) activities with respect to ordinary investment and a lower level of private external financing of these activities (Hall, 2002; Hall and Lerner, 2010). In addition, the capital structure of innovating companies would present lower levels of leverage, because banks and other sources of private financing are reluctant to lend when the investment is concentrated essentially on intangible assets. These problems are even more evident in NTBFs, where the effect of the information asymmetries entails the problem of adverse selection, because the range of variation in the real quality of the project (unobservable) can be great between "good" companies and "lemons" (Himmelberg and Petersen, 1994).

Consistent with this view, Delapierre et al. (1998) find that, although during the 1970s and early 1980s risk capital for innovation was expanding in France, in the 1990s, banks became less interested in investing in NTBFs because they lack expertise in judging technology-based ventures, evaluation work is greater than it is in other entrepreneurial projects, and as NTBFs also entail a bigger risk, the reputation of bank managers is affected. For these reasons, for technology-based companies, using their own resources is considered the natural instrument for R\&D investment (Himmelberg and Petersen, 1994). For example, for France, Delapierre et al. (1998) point out that typically half the financial assets of NTBFs at start-up are the personal assets of the founders; and, in Italy, Giudici and Paleari (2000) note that NTBFs are financed mainly with internal resources, and secondly, with short-term debt from banks. ${ }^{3}$

\footnotetext{
${ }^{3}$ Notice that the implicit monitoring of bank financing also has a beneficial effect on non-publicly traded firms. Jensen (1986) claims that financial debt can be used to motivate firms' managers and their organization to
} 
In this context, one alternative would be to resort to venture capital (VC) entities (Hall and Lerner, 2010). It is expected that they contribute to the development of the company, given that they have good information on the specific sectors they invest in, they have experience in active supervision of the entrepreneurial team's business plan and they contribute with a "signal effect" about other sources of financing (Giudici and Paleari, 2000). ${ }^{4}$ Obviously, there are different types of VC entities, for example, generalist and hightechnology. Lockett et al. (2002) note that the former face greater costs on due diligence, especially in the first stages of the NTBFs as a result of a demand for more information. This entails a higher cost of valuation among generalist venture capital entities. Once the investment is made, greater supervision of the NTBFs is needed.

Another mechanism that financers can use to lower information asymmetries is founders' patent activity, which can act as a signal of the knowledge capital of start-up firms and their potential value. Remarkable in this respect is the study by Conti et al. (2013), who develop a theoretical model in which technology startups can use the number of patents filed by the founders as a signal for external investors. They confirm that patents are endogenously chosen to attract new investors for a dataset of Israeli startups that raised VC during the period 1994-2011. However, this strategic behavior is only corroborated for rounds of funding subsequent to the first, suggesting that startups are created on the basis of founders' initial set of patents. ${ }^{5}$

At this point, it is important to distinguish between public and private VC entities. As for the most important factors when deciding to invest in a company, Ramón-Llorens and Hernández-Canovas (2010) note that, given the heterogeneity that exists among VC entities,

make efficient use of free cash flows. Ang et al. (2000) also point out the special role of banks in delegated monitoring on behalf of other shareholders: equity agency costs will be lower, the greater is monitoring of banks. And Colombo et al. (2014, p. 268) remark that 'bank monitoring encourages leveraged firms to use their assets more efficiently and discourages perquisite consumption, producing positive effects on firms' performance'.

${ }^{4}$ See also Megginson and Weiss (1991), who provide support for the certification role of VC in initial public offerings.

${ }^{5}$ In a complementary way, Czarnitzki et al. (2014) focus on the role of patents as quality signals for established R\&D-active firms. They conclude that patent activity attenuates financing constraints especially in the case of small firms where information asymmetries may be particularly high and collateral value is low. Okamuro et al. (2011) confirm the role of patents as signals of the competencies of the firms to third parties, providing evidence of their positive effect on the probability of R\&D cooperation in new Japanese businesses. Gans and Stern (2013) also suggest that a strong market of ideas reduces start-up innovators' problems of disclosure, allowing them to consider alliances with incumbent firms without fear of expropriation. 
the criteria will depend on the characteristics of these entities. That is, their goals will condition the evaluation of and criteria for selecting new proposals. In particular, public entities would have non-financial criteria, like policy and employment, as part of their objective function. But among public venture capital entities devoted to high-technology companies, the objective function stresses as selection criteria characteristics related to the management team and the company product, because its selection criteria rest on the experience of the team that evaluates the proposals. This experience allows them to become involved in early-stage investments, with an important role in orienting the product and market.

Public VC is expected to be especially relevant in Europe, as it fills the seed capital gap. However, most relevant studies that compare the effect of public VC versus private VC on European NTBFs only find a positive impact of public VC when associated with private VC funds. In particular, Grilli and Murtinu (2014a, 2014b) analyze the effect of public VC on the sales and employment growth of European high-tech entrepreneurial firms, finding that the impact of government-managed VC is negligible, and only becomes positive when public funds co-finance with private funds. In the same line, Cumming et al. (2014) investigate the effect of government versus private independent VC backing on the exit performance of entrepreneurial firms measured in terms of the likelihood of reaching a positive exit through an initial public offering or a trade-sale. They show that government VC-backed companies underperform with respect to private independent VC-backed companies, while mixed syndicates of private-independent and governmental VC investors lead to a higher (but not statistically different) likelihood of a positive exit than that of independent VC-backing. All this evidence casts doubt on the ability of governments to support NTBFs through direct and active involvement in VC markets.

However, participation in VC markets is only one of the instruments that governments have to support small, high-technology companies. In general, public intervention would be justified at least for the following reasons (Lerner, 1999, 2002): 1) because of knowledge spillovers, the social return of spending on R\&D exceeds the private return, in such a way that public intervention would help correct a market failure; 2 ) in aid programs, the public agency implicitly certifies these companies, reducing the information 
asymmetries, so public subsidies for small technology-based companies transmit information to other potential investors. ${ }^{6}$

Obviously, public intervention can also generate negative effects on entrepreneurial activity. When being awarded R\&D grants, firms may reduce their own R\&D investment, displacing or crowding out private investment (see Zúñiga-Vicente et al., 2014, for a review). As Lerner (2002) points out, interests groups or politicians may seek to allocate subsidies to benefit themselves. In this line, one possibility would be for government officials to select firms based on their likely success, regardless of the low marginal contribution of public aid. Innovation policy could also be captured by incumbents in R\&D activities. In addition, in the case of newborn firms, subsidies may distort both the post-entry market selection of efficient entrepreneurs and the learning process of new founders (Santarelli and Vivarelli, 2002, 2007). In particular, a "deadweight" effect may happen if the awarded NTBF would have survived and grown even without the aid; and a "substitution" effect may take place if the awarded new firm would have exited the market in the absence of the subsidy and, therefore, is implicitly substituting a potentially more efficient entrant.

\section{Entrepreneurs and public aid for NTBFs}

In this section, we review the literature about NTBF founders ${ }^{\prime 7}$ characteristics that can influence participation of NTBFs in public aid programs for their creation or development. This participation is the result of two decisions. First, the entrepreneurial team decides whether or not to apply for public financing. Second, the public agency decides whether or not to grant the aid, conditional on the application received. Theoretically, both decisions are influenced by different factors. However, the determinants of each decision cannot be studied separately in this research, as information about the rejected applications is unavailable. This is an important restriction because it prevents us from separating the variables that influence the self-selection of the entrepreneurial team from the variables related to the selection criteria of public organizations. These criteria can typically be

\footnotetext{
${ }^{6}$ In this last respect, see also the theoretical models developed by Kleer (2010) and Takalo and Tanayama (2010), and the empirical evidence provided by Feldman and Kelley (2006) and Meuleman and De Maeseneire (2012).

${ }^{7}$ Colombo and Grilli (2005) define founders as all persons who contribute capital and have a managerial or administrative post in the new company.
} 
designed to stimulate specific groups such as national champions (picking-the-winners strategy), companies in sectors undergoing restructuring, small and medium enterprises with greater financial limitations, or NTBFs, as is specifically the case of the NEOTEC program in Spain and the Small Business Innovation Research (SBIR) program in the United States.

Keeping this in mind, below we formulate a set of hypotheses about the net effect that some founders' characteristics have on the probability of participating in aid systems designed specifically for NTBFs. Notice that both supported and non-supported firms in our analysis are NTBFs, so they share a bundle of idiosyncratic features. From this point of view, the emphasis of this article is on finding the specific characteristics of the founders (or the business plan) that induce a higher propensity to apply for public aid and/or that it make more likely to achieve this support. Therefore, our interest is not specifically in the link between start-up characteristics and post-entry performance of NTBFs, although this link can indirectly affect the probability of participating in aid systems if a favorable post-entry performance is positively valued by private or public financers to back NTBFs.

\section{a. Human capital}

A first element that might influence the securing of public support for the creation of a company is the founders' human capital, which refers to the level of studies achieved by the entrepreneur as well as to her experience in the sector or in the creation of companies.

There is a broad consensus in the literature that founders of NTBFs have a higher level of education than founders of other new businesses (Storey and Tether, 1998). Several studies note, moreover, the existence of direct positive effects of founders' human capital on the post-entry economic performance of NTBFs, especially if the founders have professional experience in the same sector or in previous business ventures (Colombo and Grilli, 2005; Acs et al., 2007; Ganotakis, 2012; Vivarelli, 2013). For a sample of Portuguese NTBFs, Fontes and Laranja (1998) observe that most were founded by entrepreneurs that had previously worked in the business sector. Ganotakis (2012) also finds that entrepreneurial teams with high levels of formal business education and commercial, managerial or same-sector experience have created better performing NTBFs in the UK. Only general experience of more than 22 years induces a marginal reduction in the expected size 
of the company, possibly because of an excess of entrepreneurs' own trust in their abilities and knowledge, which restricts them from gathering more information that could improve their decisions.

All of that might favor access to external sources of private financing. Colombo and Grilli (2010) note that human capital has an indirect and positive effect on the growth of the company through the attraction of venture capital, which positively values a background in economics along with experience in management from some of the founders. Moreover, they find that venture capital entities attract NTBFs that put greater value on the learning in management skills that they can receive from the financial entity. Likewise, Gimmon and Levie (2010), in interviews with investors, highlight the importance that investors give to human capital when investing in an NTBF. For these same authors, relevant experience in management has the effect of attracting external resources. In addition, Honjo et al. (2014) also argument that firms managed by founders with higher levels of human capital may tend to raise more R\&D funding from capital markets, ${ }^{8}$ and that founders' human capital may signal their capabilities to external suppliers of capital when capital markets are not perfect.

As a consequence, the more human capital the entrepreneur has, the fewer restrictions there will be to accessing external financing, so public aid becomes less necessary and there are fewer incentives to apply for it, as costs of applying for public aid are generally sizeable. On the basis of these arguments, the following hypothesis is put forward:

Hypothesis 1: NTBFs created by entrepreneurs with more human capital and, in particular, more previous experience in management, are less likely to participate in public support programs for NTBFs.

\section{b. Personal aspirations}

As is well known, one of the most prominent characteristics of NTBFs that has justified public intervention is their contribution to the growth of economies. In this respect,

\footnotetext{
${ }^{8}$ However, this would not necessarily imply a lower funding gap for R\&D in these firms. In fact, when analyzing the impact of founders' human capital on the R\&D investment of start-up Japanese firms, Honjo et al. (2014) find that higher levels of founders' human capital, especially their education levels, increase both actual and required investment in R\&D.
} 
if strengthening the development of national or regional industry is among the goals of the agency, one aspect that might favor the participation of a company in the public aid system is its expectations for growth, which to a greater or lesser extent are aligned with its founders' motivations.

Along these lines, Delmar and Wiklund (2008) study the effect of motivating companies to grow on their effective behavior in terms of growth. The results obtained for a sample of small Swedish companies suggest an effect of motivation on the growth of employment, even when it is controlled by past growth that might provide feedback for the motivation. Stam and Wennberg (2009) qualify these results, remarking that R\&D and motivating growth are substitutive factors as determinants of business growth: the first is important for the growth of high-tech companies while the second is important for the growth of low-tech companies. However, as these same authors note, just as one can expect that the will to grow directly affects the effective growth of a new company, it also seems plausible that this characteristic of the entrepreneur has indirect effects on growth through stimulating R\&D, developing new products and establishing business alliances.

Therefore, if the ambition to grow has an effect on expected employment growth, it is feasible that the agency will select those business projects that declare their orientation to growth as a goal of the company's evolution. This leads to formulating the following hypothesis.

\section{Hypothesis 2: NTBFs created by entrepreneurs who project orientation to growth as a goal} of the company's evolution, are more likely to participate in public support programs for NTBFs.

Obviously, when a company is created, there might be expectations other than orientation to growth, depending on whether the entrepreneur's personal aspirations are related to, for example, getting rich, personal satisfaction or earning external recognition. If these aspirations were aligned with the goals of public agencies, they might also influence the probability of participating in support systems.

\section{c. Links to the public R\&D system}


The existence of links to the public R\&D system at the time a company is created is a factor that can contribute to reducing the costs of applying for public aid. In addition, one of the goals of the public agencies when granting the aid could be to strengthen the transfer of technology between the public sector and the private sector, which is benefited by the existence of previous links to the public R\&D system. These ties include the perception of external support from a Technology Transfer Office (TTO) as well as the participation of academics in the creation of the NTBF or the location of the NTBF in science parks or university business incubators.

With regard to TTOs, three of their fundamental tasks in their collaboration with companies are the following: (i) technically facilitate the creation and processing of projects; (ii) provide administrative support for the establishment of contracts and (iii) look for sources of financing. ${ }^{9}$ Therefore, it is likely companies that were founded with the support of a TTO will have a greater chance of applying for and obtaining public aid from the agency.

Regarding entrepreneurs' ties to the academic world, as Murray (2004) highlights, in the case of academic start-ups, university founders contribute their human capital to the company and also their relational capital, increasing the chances of technological transfer and insertion in the region's system of innovation. In this line, the founders' academic status functions as an indicator of quality for external investors, reducing the expected failure rate. Gimon and Levie (2010) confirm the positive impact of academic status on the securing of external financing for a sample of Israeli high-tech start-ups, although it does not seem to affect the probability of survival.

As for technology parks, their connection to universities and research centers facilitates the transfer of new knowledge with business applications, which makes them attractive for NTBFs that are looking for complementary assets, sharing costs and risks (Okamuro et al., 2011). Moreover, technology parks can play an important role in the support of NTBFs by facilitating access to public subsidies (Colombo and Delmastro, 2002).

\footnotetext{
${ }^{9}$ In this last respect, although it is still a limited phenomenon, one of the most pro-active initiatives would be the creation of venture capital funds directly affiliated to parent universities (and managed by the staff at TTO), which invest or co-invest with other investors in the equity capital of portfolio companies (Croce et al., 2014).
} 
From this evidence we can conclude that the links that NTBFs have to the public system of R\&D favor the transfer of technology and can reduce the costs of applying for public aid. Considering the arguments above, the following hypothesis can be advanced:

\section{Hypothesis 3: NTBFs created by entrepreneurs with linkages to the public system of R\&D,} are more likely to participate in public support programs for NTBFs.

\section{d. Previous planning}

NTBFs usually operate on the borders of established industrial sectors (Autio and YliRenko, 1998). In general terms, it is difficult to identify a market for their products and services, given that they normally concentrate on few clients. In addition, they tend to make specialized products in niche markets (Delapierre et al., 1998; Giudici and Paleari, 2000), given that large companies are inefficient in these market segments, as they are less dynamic in responding to changes in the environment and technological patterns. Given the specific nature of the niches that most of the NTBFs try to cover, access to private external financing can be facilitated by a previous definition of the company's relevant market, that is, in periods prior to the start of any activity. This would make public aid less necessary, decreasing the probability of applying for public support.

On the other hand, from the point of view of a public agency allocating credits to new firms, a prior definition of the market could be a signal of a higher success probability of the business plan and, therefore, of the founders' capacity to pay back the principal of the credit. Therefore, this previous planning of the entrepreneurial team may increase the awarding probability of public aid conditional on the application. We leave it to the empirical analysis to determine the net effect of these two opposite forces on the probability of participating in the public aid system.

\section{The NEOTEC program and the database}

An example of public support of NTBFs in Spain is the NEOTEC program, which is articulated through two initiatives: NEOTEC loans and NEOTEC venture capital. This program is run by the CDTI, the main Spanish public agency with regard to support for business R\&D\&I. 
The NEOTEC program began in November 2001 and its goal is to foster new feasible technological business projects that have potential for growth. This program tries to help technology entrepreneurs from the moment the business idea is conceived until it becomes a viable company (Del-Palacio et al., 2012).

The program consists of three phases: the proposal of business ideas, the creation of the company and, lastly, the venture capital phase. The second phase considers seed loans with no interest and no additional guarantees. These loans are worth up to $300,000 €$ and cover up to $70 \%$ of the project budget. In addition to the seed loan, companies receive support in management and consulting. The loan starts to be paid back when the company generates positive cash flow. In the third phase, venture capital firms ${ }^{10}$ are encouraged to invest in technology companies newer than two years old. In terms of its structure, the NEOTEC program is quite similar to the well-known U.S. SBIR program that helps small innovative firms (Link and Scott, 2012). However, the SBIR program is supported by 11 federal agencies, quantities awarded are capped higher, and the concept of small firm refers to companies with up to 500 employees. ${ }^{11}$ In addition, in the SBIR program, each year federal agencies identify various R\&D topics for pursuit by SMEs under the SBIR program, representing scientific and technical problems requiring innovative solutions (Wessner, 2009).

To participate in the NEOTEC initiatives, SMEs must meet the following conditions:

- Be less than four years old at the moment of applying

- Belong to a sector of activity where technology is the key competitive factor

- Have a coherent and feasible business plan, in terms of product market, technology, entrepreneurial team and financial plan.

Specifically, the CDTI finances a company plan, not only one R\&D project. As such, all the lines of activity that the company plans to undertake in the five years considered must be presented. Nonetheless, the expenses associated with R\&D activities must account for the majority of the budget for the proposal.

\footnotetext{
${ }^{10}$ This third phase linked to venture capital began in 2006.

${ }^{11}$ This employee cap is significantly larger than the employee cap of 250 employees applied in Europe for SMEs.
} 
As can be seen in Table 1, from 2001 to 2009, the NEOTEC program presents year-toyear increases in the number of companies supported, in the amount of financing and in the proportion of the total budget for the project covered by the financing, although this trend was interrupted in 2008.

\section{INSERT TABLE 1 ABOUT HERE}

To analyze the determinants of participation in this program, in this research, we use a survey for technologically-based companies made by the CDTI. The survey gathers qualitative information about the company and its founders with the goal of characterizing the profile of the technological entrepreneur. To complement this information, we consulted the SABI (Sistema de Análisis de Balances Ibéricos) database, which contains a record of annual accounts for close to one million Spanish companies. In addition, general information about the companies, like their geographical location, age or number of employees, can be obtained from the SABI database.

The survey about NTBFs was sent to around 2,000 companies: to those which received aid from the NEOTEC program between 2002 and 2010; to NTBFs located in science parks (according to the information provided by the Association of Science and Technology Parks of Spain, APTE); to participants in a venture capital forum organized by the CDTI; and to recipients of other support from the CDTI during the period 2005-2009. A total of 337 companies answered the survey. Once the information from this survey was merged with the information included in the SABI database, the final available sample consisted of 271 NTBFs, 133 of which were beneficiaries of the NEOTEC program during the period in question. In terms of representativeness, our sample accounts for $34 \%$ of all participants in the NEOTEC program during the period. This sample size is along the lines of others in international studies of NTBFs. ${ }^{12}$

Notice that, as the survey was launched in 2010, picking up past information about the firm creation process (and the information from SABI corresponds to official balance sheets that take time to register), our sample is probably biased towards surviving NTBFs. In fact, as can be seen in Figure 1, most of the firms in our sample were created after 2004. In

\footnotetext{
${ }^{12}$ See, among others, Autio and Lumme (1998), Colombo and Grilli (2005, 2010), Gimmon and Levie (2010) and Kösters (2010).
} 
addition, the distribution between participants and non-participants in the NEOTEC program shows a higher proportion of participants among firms created in the years 2005, 2006 and 2007.

\section{INSERT FIGURE 1 ABOUT HERE}

With regard to entrepreneurs' characteristics or the business plan, the information contained in the survey is qualitative, so the variables used for the analysis in this study are categorical. $^{13}$

As concerns entrepreneurs' human capital, it is possible to consider four different dimensions: (i) the highest level of education achieved by any of the founders; (ii) relevant experience in management; (iii) experience in the same sector the company operates in; and (iv) experience in creating an NTBF.

The sample reveals that founders are characterized by their high level of studies (Table 2). Fifty-one percent of the companies declare that one or more members of their teams of founders have a Master's or Doctorate degree, with a higher proportion among companies that obtain support from the NEOTEC program (60\%). As for work experience, $78 \%$ declare that they have experience in the same sector and $42 \%$ declare that they have more than 10 years of managerial experience, although this is less frequent (35\%) among NEOTEC program companies. With respect to experience in the creation of NTBFs, $49 \%$ of the companies declare that some of the founders have been involved in the creation of an NTBF. In short, founders have a high level of studies, experience in management and knowledge of the sector the company operates in. Mean difference tests indicate that the differences between participants and non-participants in NEOTEC are statistically significant in level of education (in favor of the participants) and experience in management (in favor of the non-participants).

\section{INSERT TABLE 2 ABOUT HERE}

As regards personal aspirations at the time the business starts, entrepreneurs declare in the survey whether their goal in terms of their evolution was to orient it towards growth

\footnotetext{
${ }^{13}$ In the Appendix, the exact definition of the variables used can be found.
} 
or have it reach a comfortable size. Also, they are asked about their aspirations of personal satisfaction or wealth, which they must rate on a scale of 1 to 5 . Most of the founders (75\%) declare the pursuit of growth as their goal, and this is most frequent among companies with NEOTEC support (83\%). In addition, the founders declare that the pursuit of personal satisfaction is very important, and to a much lesser extent, the pursuit of recognition and respect.

As for their links to the public system of R\&D, approximately one-fourth of the entrepreneurs declare that they had the support of a TTO when they started their activities. This is more evident among companies in the NEOTEC group (33\%) than in other NTBFs. External support of NTBFs also comes from technology parks. In total, $52 \%$ of the companies participate in these parks, and the proportions for both groups are similar. Moreover, $46 \%$ of founders of companies that participate in the NEOTEC program start their business with academic colleagues from university; among founders of other companies, this percentage is considerably lower (28\%).

With regard to planning, in the survey the entrepreneur is asked about the moment interaction with the market began with the goal of orienting the marketing of the goods or services produced by the NTBF. In general, $17 \%$ of the entrepreneurs declare that they had interacted with the market before conceiving the idea, a characteristic observed to a lesser extent among NEOTEC companies (12\%).

Along with the peculiarities of entrepreneurs and the conditions surrounding the creation of the company, one ought to take into account other characteristics of NTBFs that might influence their participation in public aid programs. Among them, being a manufacturing company, being located in Madrid, Catalonia or the Basque Country, and having more than 10 employees at the moment of creation will be considered control variables for analysis afterwards.

With respect to branch of activity, some public programs specify sectorial guidelines for target recipients of aid, especially in the case of activities with strong externalities associated with them. The NEOTEC program does not consider rules directed to a specific branch, which is why we do not expect a priori any significant effect on the probability of accessing this program. 
Regarding the geographical location of NTBFs, Storey and Tether (1998) note that proximity to universities and research centers improves flows of knowledge and information, formal as well as informal, between NTBFs and research institutes, universities and other companies, especially if the companies are clients of NTBFs, creating dynamic networks and complementarities between small and big companies in innovation. For Autio and Yli-Renko (1998), a large presence of NTBFs provides an incentive for a big company to establish an operation in the same region, using NTBFs as providers of specialized technology. Concerning the relationship with research centers, Zucker et al. (1998) empirically demonstrate that the moment and the location of new companies devoted to biotechnology ${ }^{14}$ are explained mainly by the presence of scientists who actively contribute to basic science at a time and in a place, highlighting the role of universities in fostering local development. And more in general, Bade and Nerlinger (2000) demonstrate that there is a higher birth rate of NEBTs on the outskirts of big cities as well as a strong correlation between the number of NTBFs and the location of R\&D centers.

To keep in mind these technological externalities associated with the location of companies, it is usual to identify when companies are located in regions that spend more on $R \& D$, have a higher proportion of personnel in R\&D compared to the working population, or have greater scientific production. In Spain, these regions correspond to Madrid, Catalonia and the Basque Country (OECD, 2011).

As can be seen in Table 2, $19 \%$ of the companies in the sample are manufacturers and close to half are located in the autonomous regions of Madrid, Catalonia or the Basque Country; this is true for $63 \%$ of the companies in the NEOTEC program. As for initial size, only $10 \%$ of the companies are created with more than 10 employees. It is worth noting that this proportion is significantly lower among participants in the NEOTEC program (5\%) than in the rest of the companies (14\%).

Note that certain characteristics of entrepreneurs and NTBFs might be correlated between each other. In this regard, for example, the analysis of Table 3 reveals that, although the values are relatively low, there is a positive correlation between the three

\footnotetext{
${ }^{14}$ The years researched in the study by Zucker et al. (1998) correspond to the first years that biotechnology developed its first practical applications. As such, only some researchers are privy to this knowledge, although over time, as biotechnology spreads, the returns begin to diminish.
} 
available indicators to reflect the extent of connections with the public system of R\&D. These indicators are also positively associated with the fact that the entrepreneur has postgraduate studies. All this will have to be taken into account for the interpretation of the results presented in the following section to test the hypotheses put forward.

\section{INSERT TABLE 3 ABOUT HERE}

\section{Empirical specification and results}

As previously mentioned, the probability that companies participate in an R\&D support program can be expressed as the joint probability resulting from two sequential decisions (Busom, 2000; Blanes and Busom, 2004; Huergo and Trenado, 2010). In the first place, the company decides whether or not to apply for aid from the public agency. Then, the public agency decides whether or not to grant the aid, conditional on the company's application.

From a theoretical point of view, both decisions are influenced by different factors. However, in this study, it is not possible to separately estimate both probabilities, as there is no information about rejected applications in the database. As such, it is not possible to distinguish the weight of the different factors in the decision to apply for and in the decision to award public aid. Consequently, the net effect of the different factors is determined, estimated through a Probit-type discrete choice model.

Notice that this inability to distinguish between the two mentioned decisions might make that an explanatory variable appear non-significant for the joint probability, while having a positive impact on one of the decisions that is wholly compensated by a negative impact on the other decision. A non-significant effect could also be compatible with an absence of effect on both decisions. In the same line, a positive (negative) global impact can be explained by two positive (negative) effects that reinforce each other or by a unique positive (negative) effect on one of the decisions that prevails over the negative (positive) or null effect on the other decision.

The results are presented in Table 4 for seven different specifications. It is worth noting that the majority of the explanatory variables are dichotomous. As such, we will 
estimate the marginal effects as the change from not having the characteristic to having it and only in the case of continuous variables will the effect be evaluated on the average of the variables.

\section{INSERT TABLE 4 ABOUT HERE}

The first four specifications correspond to models that, along with the control variables, sequentially incorporate the blocks of variables associated with each hypothesis, while the estimations of columns (5) to (7) show the results of adding each block as an alternative to the previous one.

Included as control variables in all the estimations are three dichotomous variables which indicate whether the company is a manufacturer, whether it is located in Madrid, Catalonia or the Basque Country and whether its size at the moment of creation was greater than 10 employees. As can be observed, there are no significant differences between manufacturing companies and service companies. However, having a size larger than 10 employees reduces the probability of obtaining public aid from the agency. The agency is less sensitive to supporting larger companies with the NEOTEC program, probably because they can be supported through other more general programs devoted to innovation. In addition, it is confirmed that the probability of participating is higher when the company is located in the autonomous regions of Madrid, Catalonia or the Basque Country, regions where the great majority of indicators of innovation stand out with respect to the rest of the autonomous regions (OECD, 2011).

With regard to human capital (column (1) of Table 4), neither experience in the sector nor experience as a founder seem to have an effect on participation in NEOTEC. Contrary to what was expected, postgraduate studies increase the probability of participating. However, that might be because there is a high correlation between this variable and those that reflect the connection of the NTBF project to the public system of R\&D. In fact, when the latter are added to the estimation (column (3) of Table 4), postgraduate studies cease to be significant.

In addition, having relevant experience in management reduces the probability of participating by close to 20 percentage points, confirming Hypothesis 1 . This result, which 
holds in all the estimations where this variable is introduced, is in line with the greater accessibility to resources that companies with founders greatly experienced in management have.

As for founders' aspirations at the time the company is created, striving for recognition plays against their participation in the aid program, while seeking personal satisfaction is positively related to their probability of participating in the aid program (column (5) of Table 4), although this relationship is weaker depending on the rest of the variables included in the specification.

However, it is orientation to growth as the goal of the company's evolution that has a greater impact, such that NTBFs with entrepreneurs who declare to have this goal are around 20 percent more likely to be supported. This result confirms our Hypothesis 2, although it contradicts what Kösters (2010) and Cantner and Kösters (2012) find for the eastern German state of Turingia: that expected sales growth is not related to the awarding of financial aid. This would imply that German and Spanish public agencies pursue different goals with the design of their programs.

The third block of variables analyzed refers to the connections of the NTBF and its entrepreneurial team to the public system of R\&D (columns (3), (4) and (6) of Table 4). As Cantner and Kösters (2012) find, in Spain, creating a company with academic colleagues seems to be positively valued by the agency. Likewise, although location in a technology park does not seem to have an impact, having the support of a TTO increases the probability of having public support, and generally, this set of variables is significant, which would confirm our Hypothesis 3.

Finally, with regard to planning, previous interaction with the market (columns (4) and (7) of Table 4) has a negative impact on the awarding of public aid. Also note that, as occurs with experience in management, the effect of planning is slightly less when this variable is included in isolation than when it is inserted in the rest of the blocks. That might be indicating that both factors are reinforced, facilitating access to private external financing and discouraging the company from applying for public aid. 
In general, the complete specification presents a good fit, ${ }^{15}$ correctly predicting $72.2 \%$ of the companies that participate in the NEOTEC program and $72.5 \%$ of the companies that do not participate. In short, companies whose founders have less experience in management, are oriented to growth, have the support of a TTO, are academic entrepreneurs, have not previously interacted with the market or are in Spanish regions which excel in R\&D are more likely to participate in the public aid program. However, experience in the sector or in the founding of another NTBF and location in a technology park are not relevant factors.

To assess the robustness of our results, we also take into account that participation in the NEOTEC program could be related to success in achieving private external financing. In this sense, in the survey made by the CDTI each firm also indicates whether it had access to banking financing during the first three years of the firm's existence. This allows us to estimate a bivariate Probit model to study the determinants of getting each type of external support for the creation of the firm.

\section{INSERT TABLE 5 ABOUT HERE}

The results are reported in Table 5. The specification includes the same control variables as in column (4) of Table 4. In terms of the sign and significance of the coefficients, the determinants of participation in the public aid program remain unchanged. Regarding the probability of obtaining external private funds, contrary to previous evidence (Colombo and Grilli, 2010; Gimmon and Levie, 2010), the variables related to human capital are nonstatistically significant or have a weak negative impact, as in the case of previous experience in the sector. However, the absence of effect of postgraduate education might again be explained by the correlation between this characteristic and being an academic entrepreneur. In fact, the founders' academic status has a clear positive effect on the propensity to raise private funds, which is consistent with the role of this academic status as an indicator of quality for external investors (Gimon and Levie, 2010). Also having support from a TTO, and the pursuit of personal satisfaction and recognition increase the probability of having access to private external financing, while the rest of the founders' features do not

\footnotetext{
${ }^{15}$ The Hosmer-Lemeshow specification test is used. This test assesses the goodness of fit, comparing the sample frequency of the observed dependent variable with the adjusted probability among subgroups of observations. See Cameron and Trivedi (2010).
} 
seem to play any role. Nevertheless, these results should be taken with caution, given that the sample defined for this study was extracted to specifically analyze participation in the NEOTEC program, and we cannot evaluate its representativeness for studying access to other external sources of financing.

Notice also that coefficient rho of correlation between the equations is not significant, suggesting an absence of contemporaneous correlation between obtaining public financing through the NEOTEC program and achieving private external financing from the banking system. Obviously, a deeper analysis of the determinants of private external financing would require considering potential dynamic links between different types of financing. ${ }^{16}$ However, we cannot handle this subject with our database, as the information on financing refers only to the first years of the firm's existence.

\section{Discussion and conclusions}

The objective of this study is to identify which characteristics of entrepreneurs determine the participation of Spanish companies in financial aid programs designed for NTBFs. The analysis considers the net effect of these characteristics on the entrepreneur's decision to apply for financing within the framework of the NEOTEC program and the decision by the CDTI, the public agency that runs the program, to grant the aid.

To this end, we have access to a unique database on the profile of Spanish technology entrepreneurs, allowing us to analyze the determinants of NTBFs' participation in the NEOTEC program between 2001 and 2009. Specifically, there are four dimensions evaluated: the entrepreneurs' human capital, the connections of the NTBF and its founders to the public system of $R \& D$, the motivations at the time of creating the company and the extent of initial planning.

The results obtained by estimating Probit models for the probability of participating in the NEOTEC program allow us to highlight the following conclusions:

\footnotetext{
${ }^{16}$ In particular, as we mention in Section II, being supported by the public agency could cause a 'certification' effect. Banking institutions can use this information as a 'signal' of the quality of the project.
} 
In the first place, as concerns the entrepreneur's human capital, the results are not conclusive. On one hand, as was expected, we obtain evidence that having relevant experience in management reduces the probability of participating in the public program, which is coherent with greater access to private external resources which founders with extensive experience in business management can normally resort to. On the other hand, having postgraduate studies seems to increase a founder's probability of participating in the public program, although that might be explained by the high correlation between this feature and being an academic entrepreneur. This also implicitly entails closer connections of the NTBF project to the public system of R\&D. In fact, when the factors indicative of these links are added to the specification, postgraduate studies cease to be relevant.

Secondly, our empirical results with regard to founders' motivations suggest that seeking recognition diminishes the probability of participating in the aid program, while seeking personal satisfaction and, above all, the goal of orientation to growth have a positive effect. This evidence contributes to amplifying the knowledge of behavioral aspects and their relation to public support. Although in any allocation there are informal aspects that are assessed by the agency, they have not been systematically compiled by the literature related to technology companies. In this regard, it is novel to be able to assess the role that personal motivations play in participating in public aid systems.

Thirdly, we find that, although location in technology parks is not relevant for receiving public aid, having help from TTOs or academics on the entrepreneurial team positively influence participation in the NEOTEC program, confirming the favorable role of connections to the public system of R\&D. This might be because support from TTOs makes it possible to reduce the costs of applying for public aid, and because the agency positively evaluates the relational capital of academic entrepreneurs, which increases the possibility of technological transfer and insertion into the regional system of innovation.

Finally, the planning of the entrepreneurial team, measured by the existence of interaction with the market previous to developing the idea with the goal of orienting the marketing of the products made by the NTBF, has a negative impact on the probability of participating in the public program. This is coherent with the idea that more initial planning facilitates access to private external financing, making public aid less necessary. 
In this regard, the limitation of the analysis performed resides in the impossibility of separating the impact of entrepreneurs' characteristics on the decision to apply for public financing from the public agency's decision to award aid. Having a larger sample of companies and more information about rejected applications would allow us to qualify these conclusions, and would point to a natural extension of this research.

\section{References}

Acs, Z.J., Armington, C., Zhang, T. (2007): "The determinants of new-firm survival across regional economies: the role of human capital stock and knowledge spillover", Papers in Regional Science, 86, 367-391.

Acs, Z.J., Audretsch, D.B. (2003): Handbook of entrepreneurship research: An interdisciplinary survey and introduction, New York: Springer.

Aernoudt, R. (2004): "Incubators: tool for entrepreneurship?" Small Business Economics, 23, 127-135.

Almus, M., Nerlinger, E. (1999): "Growth of new technology-based firms: which factors matter?" Small Business Economics, 13, 141-154.

Ang, J.S., Cole, R.A., Lin, J.W. (2000): "Agency costs and ownership structure", The Journal of Finance, 55(1), 81-106.

Autio, E., Lumme, A. (1998): "Does the innovator role affect the perceived potential for growth? Analysis of four types of new, technology-based firms", Technology Analysis \& Strategic Management, 10, 41-54.

Autio, E., Yli-Renko, H. (1998): “New, technology-based firms in small open economies-An analysis based on the Finnish experience", Research Policy, 26(9), 973-987.

Bade, F-J., Nerlinger, E. (2000): “The spatial distribution of new technology-based firms: Empirical results for West-Germany", Papers Regional Science, 79, 155-176.

Blanes, J., Busom, I. (2004): "Who participates in R\&D subsidy programs? The case of Spanish manufacturing firms", Research Policy, 33, 1459-1476.

Busom, I. (2000): "An empirical evaluation of the effects of R\&D Subsidies", Economics of Innovation and Technology, 9(2), 111-148.

Cameron, A., Trivedi, P. (2010): Microeconometrics Using Stata, Revised Edition, Stata Press.

Cantner, U., Kösters, S. (2012): "Picking the winner? Empirical evidence on the targeting of R\&D subsidies to start-ups", Small Business Economics, 39(4), 921-936. 
Cincera, M., Veugelers, R. (2013): “Young leading innovators and the EU's R\&D intensity gap", Economics of Innovation and New Technology, 22(2), 177-198.

Cincera, M., Veugelers, R. (2014): "Differences in the rates of return to R\&D for European and US young leading R\&D firms", Research Policy, 43, 1413-1421.

Colombo, M.G., Croce, A., Murtinu, S. (2014): “Ownership structure, horizontal agency costs and the performance of high-tech entrepreneurial firms", Small Business Economics, $42,265-282$.

Colombo, M.G., Delmastro, M. (2002): "How effective are technology incubators? Evidence from Italy", Research Policy, 31, 1103-1122.

Colombo, M.G., Grilli, L. (2005): “Founders' human capital and the growth of new technology-based firms: A competence-based view", Research Policy, 34, 795-816.

Colombo, M.G., Grilli, L. (2010): “On growth drivers of high-tech start-ups: Exploring the role of founders' human capital and venture capital", Journal of Business Venturing, 25, 610-626.

Colombo, M.G., Grilli, L., Murtinu, S. (2011): "R\&D subsidies and the performance of hightech start-ups", Economics Letters, 112(1), 97-99.

Colombo, M.G., Grilli, L., Murtinu, S., Piscitello, L., Piva, E. (2009): “Effects of International R\&D alliances on performance of high-tech start-ups: a longitudinal analysis", Strategic Entrepreneurship Journal, 3(4), 346-368.

Conti, A., Thursby, M.C., Thursby, J. (2013): "Patents as signals for startup financing", The Journal of Industrial Economics, 61(3), 592-622.

Croce, A., Grilli, L., Murtinu, S. (2014): "Venture capital enters academia: an analysis of university-managed funds", The Journal of Technology Transfer, 39(5), 688-715.

Cumming, D.J., Grilli, L., Murtinu, S. (2014): "Governmental and independent venture capital investments in Europe: a firm-level performance analysis", Journal of Corporate Finance, forthcoming, DOI: 10.1016/j.jcorpfin.2014.10.016.

Czarnitzki, D., Delanote, J. (2013): "Young Innovative Companies: the new high-growth firms?" Industrial and Corporate Change, 22(5), 1315-1340.

Czarnitzki, D., Hall, B. H., Hottenrott, H. (2014): "Patents as quality signals? The implications for financing constraints on R\&D", NBER Working Paper 19947, National Bureau of Economic Research, Cambridge, Massachusetts.

Delapierre, M., Madeuf, B., Savoy, B. (1998): "NTBFs-the French case", Research Policy, 26(9), 989-1003.

Delmar, F., Wiklund, J. (2008): “The Effect of Small Business Managers' Growth Motivation on Firm Growth: A Longitudinal Study", Entrepreneurship Theory and Practice, 32(3), 437-457. 
Del-Palacio, I., Zhang, X., Sole, F. (2012): "The capital gap for small technology companies: public venture capital to the rescue?" Small Business Economics, 38, 283-301.

Feldman, M.P., Kelley, M.R. (2006): "The ex-ante assessment of knowledge spillovers: Government R\&D policy, economic incentives and private firm behavior", Research Policy, 35(10), 1509-1521.

Fontes, M., Laranja, M. (1998): “Creative adaptation: the role of new technology based firms in Portugal", Research Policy, 26(9), 1023-1036.

Fontes, M., Coombs, R. (2001): "Contribution of new technology-based firms to the strengthening of technological capabilities in intermediate economies", Research Policy, 30, 79-97.

Fukugawa, N. (2006): "Science parks in Japan and their value-added contributions to new technology-based firms", International Journal of Industrial Organization, 24, 381400 .

Ganotakis, P. (2012): “Founders' human capital and the performance of UK new technology based firms", Small Business Economics, 39, 495-515.

Gans, J.S., Stern S. (2003): "The product market and the market for "ideas": commercialization strategies for technology entrepreneurs", Research Policy, 32, 333-350.

Gimmon, E., Levie, J. (2010): “Founder's human capital, external investment, and the survival of new high-technology ventures", Research Policy, 39, 1214-1226.

Giudici, G., Paleari, S. (2000): "The Provision of Finance to Innovation: A Survey Conducted among Italian Technology-Based Small Firms", Small Business Economics, 14, 37-53.

Grilli, L., Murtinu, S. (2012): "Do public subsidies affect the performance of new technologybased firms? The importance of evaluation schemes and agency goals", Prometheus, 30(1), 97-111.

Grilli, L., Murtinu, S. (2014a): "Government, venture capital and the growth of European high-tech entrepreneurial firms", Research Policy, 43(9), 1523-1543.

Grilli, L., Murtinu, S. (2014b): “New technology-based firms in Europe: market penetration, public venture capital, and timing of investment", Industrial and Corporate Change, forthcoming, DOI: 10.1093/icc/dtu025.

Hall, B. (2002): "The financing of research and development", Oxford Review of Economic Policy, 18(1), 35-51.

Hall, B., Lerner, J. (2010): "The Financing of R\&D and Innovation", Handbook of the Economics of Innovation, Vol. 1, 609-639.

Himmelberg, C., Petersen, B. (1994): "R\&D and Internal finance: A panel study of small firms in high-tech industries", The Review of Economics and Statistics, 76(1), 38-51. 
Huergo, E., Trenado, M. (2010): "The Application for and the Awarding of Low-Interest Credits to Finance R\&D Projects", Review of Industrial Organization, 37, 237-259.

Honjo, Y., Kato, M., Okamuro, H. (2014): “R\&D investment of start-up firms: does founders' human capital matter?" Small Business Economics, 42, 207-220.

Jensen, M.C. (1986): "Agency costs of free cash flow, corporate finance, and takeovers", American Economic Review, 76, 323-329.

Kleer, R. (2010): "Government R\&D subsidies as a signal for private investors", Research Policy, 39(10), 1361-1374.

Kösters, S. (2010): "Subsidizing Start-Ups: Policy Targeting and Policy Effectiveness", Journal of Industry, Competition and Trade, 10(3-4), 199-225.

Lerner, J. (1999): "The Government as Venture Capitalist: The Long-Run Impact of the SBIR Program", The Journal of Business, 72(3), 285-318.

Lerner, J. (2002): "When bureaucrats meet entrepreneurs: the design of effective 'public venture capital' programmes", The Economic Journal, 112(477), F73-F84.

Licht, G., Nerlinger, E. (1998): “New technology-based firms in Germany: a survey of the recent evidence", Research Policy, 26(9), 933-946.

Link, A., Scott, J. (2012): "Employment growth from the Small Business Innovation Research program", Small Business Economics, 39, 265-287.

Lockett, A., Murray, G., Wright, M. (2002): "Do UK venture capitalists still have a bias against investment in new technology firms", Research Policy, 31, 1009-1030.

Lockett, A., Siegel, D., Wright, M., Ensley, M. (2005): "The creation of spin-off firms at public research institutions: Managerial and policy implications", Research Policy, 34, 981993.

Löfsten, H., Lindelöf, P. (2002): "Science Parks and the growth of new technology-based firms-academic-industry links, innovation and markets", Research Policy, 31, 859876.

Megginson, W.L., Weiss, K.A. (1991): "Venture capitalist certification in initial public offerings", The Journal of Finance, 46(3), 879-903.

Meuleman, M., De Maeseneire, W. (2012): “Do R\&D subsidies affect SMEs' access to external financing?" Research Policy, 41(3), 580-591.

Mian, S.A. (1996): "Assessing value-added contributions of university technology business incubators to tenant firms", Research Policy, 25, 325-335.

Morandi, V. (2013): "The management of industry-university joint research projects: how do partners coordinate and control R\&D activities?" The Journal of Technology Transfer, 38, 69-92. 
Murray, F. (2004): "The role of academic inventors in entrepreneurial firms: sharing the laboratory life", Research Policy, 33, 643-659.

OECD (2011): OECD Reviews of Regional Innovation: Regions and Innovation Policy, OECD Publishing.

Okamuro, H., Kato, M., Honjo Y. (2011): “Determinants of R\&D cooperation in Japanese start-ups", Research Policy, 40, 728-738.

Ortega-Argilés R., Vivarelli, M., Voigt, P. (2009): "R\&D in SMEs: A Paradox?" Small Business Economics, 33, 3-11.

Hinard de Pádua, M., Duarte, J.C., von Tuzelman, G.N. (2002): "Biotechnology in an 'intermediate economy': demand and supply in Portugal", International Journal of Technology Management, 4, 129-151.

Phan, P.H., Siegel, D.S., Wright, M. (2005): "Science parks and incubators: observations, synthesis and future research", Journal of Business Venturing, 20, 165-182.

Ramón-Llorens, M., Hernández-Canovas, G. (2010): "Venture capitalists in Spain: cluster analysis of criteria used in the screening process", Working Paper 2010-08, Series EC, Instituto Valenciano de Investigaciones Económicas (IVIE). Available at: http://www.ivie.es/downloads/docs/wpasec/wpasec-2010-08.pdf

Revest, V., Sapio, A. (2012): "Financing technology-based small firms in Europe: what do we know?" Small Business Economics, 39, 179-205.

Santarelli, E., Vivarelli, M. (2002): “Is subsidizing entry an optimal policy?" Industrial and Corporate Change, 11(1), 39-52.

Santarelli, E., Vivarelli, M. (2007): “Entrepreneurship and the process of firms' entry, survival and growth", Industrial and Corporate Change, 16, 455-488.

Siegel, D.S., Westhead, P., Wright, M. (2003): “Assessing the impact of university science parks on research productivity: exploratory firm-level evidence from the United Kingdom", International Journal of Industrial Organization, 21, 1357-1369.

Soetanto, D.P., Jack, S.L. (2013): "Business incubators and the networks of technology-based firms", The Journal of Technology Transfer, 38, 432-453.

Stam, E., Wennberg, K. (2009): "The roles of R\&D in new firm growth", Small Business Economics, 33, 77-89.

Storey, D., Tether, B. (1998): “New technology-based firms in the European Union: an introduction", Research Policy, 26(9), 1005-1022.

Storey, D., Tether, B. (1998b): "Public policy measures to support new technology-based firms in the European Union", Research Policy, 26(9), 1037-1057. 
Takalo, T., Tanayama, T. (2010): “Adverse selection and financing of innovation: is there a need for R\&D subsidies?" The Journal of Technology Transfer, 35(1), 16-41.

Vivarelli, M. (2013): "Is entrepreneurship necessarily good? Microeconomic evidence from developed and developing countries", Industrial and Corporate Change, 22, 14531495.

Wessner, Ch. (2009): "The innovation imperative and the role of SBIR innovation awards". In Welfens, P.J.J.; Addison, J.T. (Eds.), Innovation, Employment and Growth Policy Issues in the EU and the US, Springer Berlin, Heidelberg, 173-187.

Zucker, L., Darby, M., Brewer, M. (1998): "Intellectual human capital and the birth of U.S. biotechnology enterprises", The American Economic Review, 88(1), 290-306.

Zúñiga-Vicente, J.A., Alonso-Borrego, C., Forcadell, F.J., Galán, J.I. (2014): “Assessing the effect of public subsidies on firm R\&D investment: a survey", Journal of Economic Surveys, 28 (1), 36-67. 


\section{Appendix: Definitions of Variables}

\begin{tabular}{|c|c|c|c|}
\hline \multirow{2}{*}{\multicolumn{2}{|c|}{ Dependent variables: }} & NEOTEC Company & $\begin{array}{l}\text { Dummy variable that takes the value } 1 \text { if the company received public support through the NEOTEC } \\
\text { program. }\end{array}$ \\
\hline & & Private external financing & $\begin{array}{l}\text { Dummy variable that takes the value } 1 \text { if the company received private external financing during the } \\
\text { first three years of existence. }\end{array}$ \\
\hline \multirow{14}{*}{$\begin{array}{l}\text { Independent } \\
\text { variables: }\end{array}$} & \multirow{4}{*}{$\begin{array}{l}\text { Human } \\
\text { capital }\end{array}$} & Postgraduate & $\begin{array}{l}\text { Dummy variable that takes the value } 1 \text { if at least one member of the founding team has a Master's or } \\
\text { Ph.D. as their maximum level of studies attained. }\end{array}$ \\
\hline & & Managerial experience & $\begin{array}{l}\text { Dummy variable that takes the value } 1 \text { if at least one member of the founding team has } 10 \text { or more } \\
\text { years of managerial experience. }\end{array}$ \\
\hline & & Experience in sector & $\begin{array}{l}\text { Dummy variable that takes the value } 1 \text { if at least one member of the founding team has three or } \\
\text { more years of experience in the sector of her present company. }\end{array}$ \\
\hline & & Experience as a founder & $\begin{array}{l}\text { Dummy variable that takes the value } 1 \text { if at least one member of the founding team has been } \\
\text { involved in the creation of an earlier NTBF that failed. }\end{array}$ \\
\hline & \multirow{3}{*}{$\begin{array}{l}\text { Personal } \\
\text { aspirations }\end{array}$} & Orientation to growth & $\begin{array}{l}\text { Dummy variable that takes the value } 1 \text { if the founders declare orientation to growth as the goal of the } \\
\text { NTBF's evolution. }\end{array}$ \\
\hline & & Personal Satisfaction & $\begin{array}{l}\text { Variable on a Likert scale for the importance of personal satisfaction in the decision to create the } \\
\text { company. The value } 1 \text { denotes little influence and the value } 5 \text { denotes much influence. }\end{array}$ \\
\hline & & Recognition & $\begin{array}{l}\text { Variable on a Likert scale for the importance of recognition and respect in the decision to create the } \\
\text { company. The value } 1 \text { denotes little influence and the value } 5 \text { denotes much influence. }\end{array}$ \\
\hline & \multirow{3}{*}{$\begin{array}{l}\text { Link to the } \\
\text { public system } \\
\text { of } R \& D\end{array}$} & TTO support & $\begin{array}{l}\text { Dummy variable that takes the value } 1 \text { if the company has the external support of a Technology } \\
\text { Transfer Office (TTO) at the time of its creation. }\end{array}$ \\
\hline & & Location in technology park & Dummy variable that takes the value 1 if the company is located in a technology or science park. \\
\hline & & Academic entrepreneurs & $\begin{array}{l}\text { Dummy variable that takes the value } 1 \text { if the founding team set up the company with university } \\
\text { colleagues or academics. }\end{array}$ \\
\hline & Planning & $\begin{array}{l}\text { Previous interaction with } \\
\text { market }\end{array}$ & $\begin{array}{l}\text { Dummy variable that takes the value } 1 \text { if the founding team began to interact with the market to } \\
\text { market the product before doing anything with regard to the company. }\end{array}$ \\
\hline & \multirow{3}{*}{$\begin{array}{l}\text { Other } \\
\text { Variables }\end{array}$} & Manufacturer & Dummy variable that takes the value 1 if the company operates in the manufacturing sector. \\
\hline & & $\begin{array}{l}\text { Created with more than } 10 \\
\text { employees }\end{array}$ & $\begin{array}{l}\text { Dummy variable that takes the value } 1 \text { if the company has } 10 \text { or more employees during the first year } \\
\text { of existence. }\end{array}$ \\
\hline & & $\begin{array}{l}\text { Madrid-Catalonia-Basque } \\
\text { Country }\end{array}$ & $\begin{array}{l}\text { Dummy variable that takes the value } 1 \text { if the company is located in the autonomous regions of } \\
\text { Madrid, Catalonia or the Basque Country. }\end{array}$ \\
\hline
\end{tabular}


Figure 1: Distribution of participants in the NEOTEC program according to the year the company was created

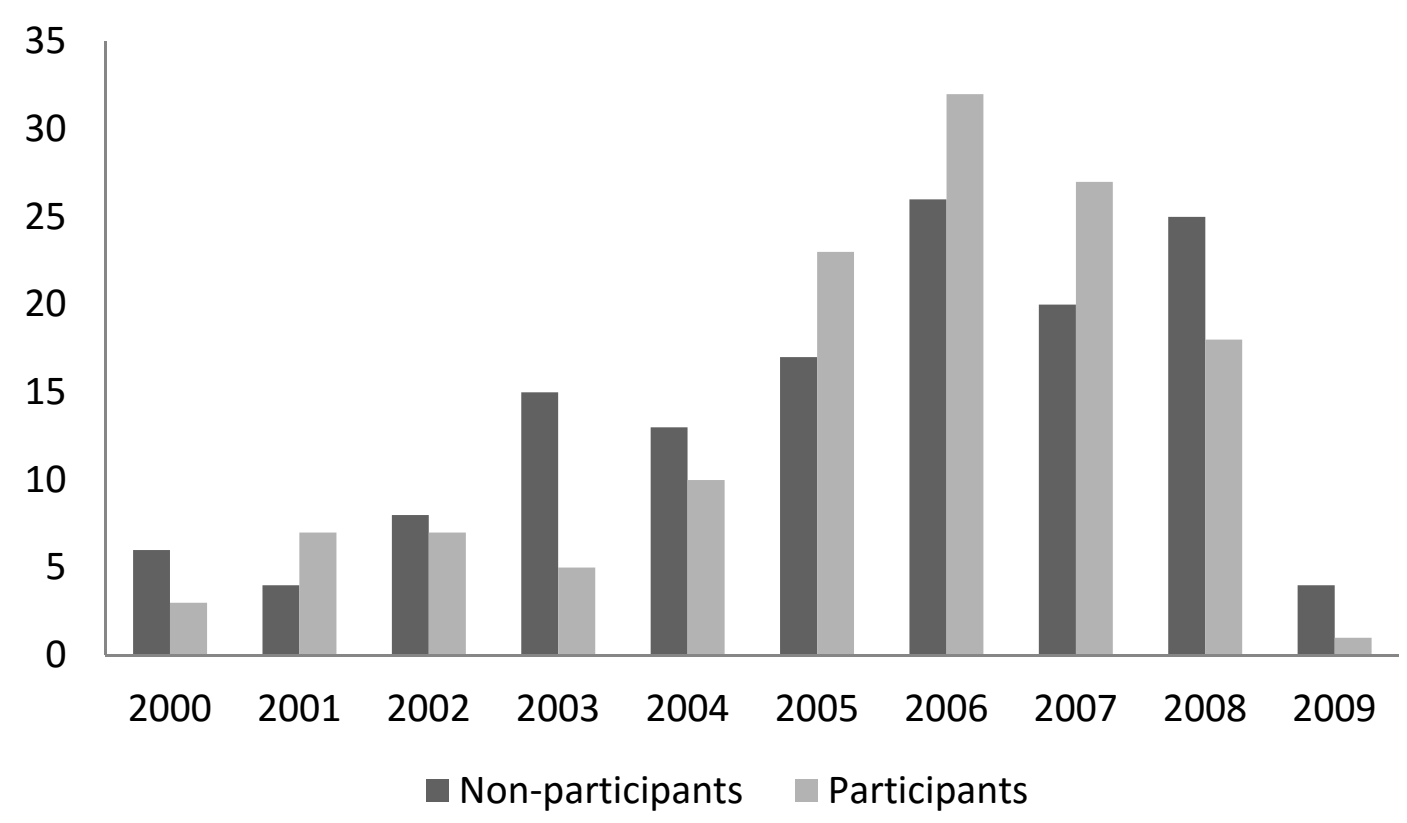

Source: Own elaboration from CDTI database 
Table 1: Financing through the NEOTEC program from 2002 to 2009

\begin{tabular}{cccc}
\hline Year & $\begin{array}{c}\text { Number of } \\
\text { companies supported }\end{array}$ & $\begin{array}{c}\text { Total subsidy } \\
\text { (in thousands of } \\
\text { euros) }\end{array}$ & $\begin{array}{c}\text { Percentage of } \\
\text { financing }\end{array}$ \\
\hline 2002 & 31 & 8,583 & 52.3 \\
2003 & 34 & 9,168 & 47.4 \\
2004 & 38 & 10,985 & 46.6 \\
2005 & 46 & 15,225 & 51.0 \\
2006 & 51 & 17,695 & 54.6 \\
2007 & 57 & 19,124 & 55.3 \\
2008 & 73 & 25,719 & 58.1 \\
2009 & 58 & 19,920 & 61.5 \\
\hline
\end{tabular}

Source: Own elaboration from CDTI database 
Table 2: Descriptive statistics

\begin{tabular}{|c|c|c|c|c|c|c|c|}
\hline \multirow{2}{*}{ Variables } & & \multirow{2}{*}{$\begin{array}{c}\text { Range of } \\
\text { values }\end{array}$} & \multicolumn{3}{|c|}{ Average values } & \multirow[b]{2}{*}{$t$-test } & \multirow[b]{2}{*}{ [p-value] } \\
\hline & & & $\begin{array}{c}\text { Total } \\
\text { sample }\end{array}$ & $\begin{array}{l}\text { Participants } \\
\text { in NEOTEC }\end{array}$ & $\begin{array}{c}\text { Non- } \\
\text { participants }\end{array}$ & & \\
\hline \multirow{4}{*}{ Human capital } & Postgraduate & $0-1$ & 0.51 & 0.60 & 0.41 & -3.15 & {$[0.001]$} \\
\hline & Experience in management & $0-1$ & 0.42 & 0.35 & 0.50 & 2.59 & {$[0.010]$} \\
\hline & Experience in sector & $0-1$ & 0.78 & 0.81 & 0.75 & -1.17 & {$[0.245]$} \\
\hline & Experience as a founder & $0-1$ & 0.49 & 0.50 & 0.48 & -0.29 & {$[0.768]$} \\
\hline \multirow{3}{*}{ Personal aspirations } & Orientation to growth & $0-1$ & 0.75 & 0.83 & 0.67 & -2.95 & {$[0.003]$} \\
\hline & Personal satisfaction & $1-5$ & 4.58 & 4.69 & 4.48 & -2.59 & {$[0.010]$} \\
\hline & Recognition & $1-5$ & 1.90 & 1.72 & 2.08 & 2.71 & {$[0.007]$} \\
\hline \multirow{3}{*}{$\begin{array}{l}\text { Link to public } \\
\text { system of R\&D }\end{array}$} & TTO support & $0-1$ & 0.23 & 0.33 & 0.12 & -4.18 & {$[0.000]$} \\
\hline & Location in technology park & $0-1$ & 0.52 & 0.52 & 0.52 & 0.05 & [0.962] \\
\hline & Academic entrepreneurs & $0-1$ & 0.37 & 0.46 & 0.28 & -3.04 & {$[0.002]$} \\
\hline Planning & Previous interaction with market & $0-1$ & 0.17 & 0.12 & 0.22 & 2.15 & [0.033] \\
\hline \multicolumn{2}{|l|}{ Manufacturer } & $0-1$ & 0.19 & 0.16 & 0.21 & 1.40 & [0.163] \\
\hline \multicolumn{2}{|c|}{ Created with more than 10 employees } & $0-1$ & 0.10 & 0.05 & 0.14 & 2.85 & [0.005] \\
\hline \multicolumn{2}{|c|}{ Madrid-Catalonia-Basque Country } & $0-1$ & 0.47 & 0.63 & 0.31 & -5.55 & [0.000] \\
\hline \multicolumn{2}{|c|}{ No private external financing Year 1} & $0-1$ & 0.62 & 0.68 & 0.56 & -2.02 & [0.045] \\
\hline \multicolumn{2}{|c|}{ Financed with venture capital Year 1} & $0-1$ & 0.10 & 0.11 & 0.09 & -0.53 & [0.597] \\
\hline \multicolumn{2}{|l|}{ Number of companies } & & 271 & 133 & 138 & & \\
\hline
\end{tabular}

Note: $t$-test denotes the difference of averages test between participants and non-participants in NEOTEC. The test corresponds to the Wilcoxon rank-sum test (MannWhitney) for discrete variables. 
Table 3: Pairwise correlation matrix

\begin{tabular}{|c|c|c|c|c|c|c|c|c|c|c|c|c|c|c|c|c|}
\hline & Variables & 1 & 2 & 3 & 4 & 5 & 6 & 7 & 8 & 9 & 10 & 11 & 12 & 13 & 14 & 15 \\
\hline 1 & NEOTEC company & 1 & & & & & & & & & & & & & & \\
\hline 2 & Postgraduate & 0.188 & 1 & & & & & & & & & & & & & \\
\hline 3 & Experience in management & -0.156 & -0.092 & 1 & & & & & & & & & & & & \\
\hline 4 & Experience in sector & 0.071 & 0.068 & 0.164 & 1 & & & & & & & & & & & \\
\hline 5 & Experience as a founder & 0.018 & -0.026 & 0.104 & -0.076 & 1 & & & & & & & & & & \\
\hline 6 & Orientation to growth & 0.177 & 0.126 & 0.153 & 0.066 & -0.134 & 1 & & & & & & & & & \\
\hline 7 & Personal satisfaction & 0.155 & 0.077 & -0.022 & 0.135 & 0.065 & 0.157 & 1 & & & & & & & & \\
\hline 8 & Recognition & -0.162 & -0.073 & 0.224 & 0.027 & 0.031 & 0.120 & 0.113 & 1 & & & & & & & \\
\hline 9 & TTO support & 0.249 & 0.162 & 0.002 & 0.070 & -0.101 & 0.067 & 0.019 & 0.047 & 1 & & & & & & \\
\hline 10 & Location in technology park & -0.003 & 0.144 & 0.003 & -0.023 & -0.202 & -0.011 & -0.035 & -0.003 & 0.128 & 1 & & & & & \\
\hline 11 & Academic entrepreneurs & 0.182 & 0.236 & -0.038 & -0.097 & -0.041 & 0.072 & 0.030 & -0.024 & 0.284 & 0.199 & 1 & & & & \\
\hline 12 & Previous interaction with market & -0.129 & -0.044 & 0.109 & 0.024 & 0.110 & 0.103 & 0.103 & -0.050 & -0.032 & 0.100 & -0.061 & 1 & & & \\
\hline 13 & Manufacturer & -0.085 & -0.155 & 0.150 & 0.007 & 0.050 & 0.023 & 0.009 & 0.110 & -0.016 & -0.057 & -0.062 & 0.029 & 1 & & \\
\hline 14 & Created with more than 10 employees & -0.169 & -0.054 & -0.026 & -0.071 & 0.059 & 0.015 & -0.058 & 0.153 & -0.086 & -0.013 & -0.067 & 0.086 & 0.064 & 1 & \\
\hline 15 & Madrid-Catalonia-Basque Country & 0.321 & 0.071 & -0.013 & 0.012 & 0.076 & 0.100 & 0.096 & -0.099 & -0.028 & -0.105 & -0.075 & -0.011 & -0.176 & -0.080 & 1 \\
\hline
\end{tabular}

Note: In bold type if the correlations are significant at $95 \%$. 
Table 4: Probability of participating in the NEOTEC program. Probit Model

\begin{tabular}{|c|c|c|c|c|c|c|c|c|c|}
\hline & & \multicolumn{2}{|l|}{ (1) } & \multicolumn{2}{|l|}{$(2)$} & \multicolumn{2}{|c|}{ (3) } & \multicolumn{2}{|c|}{ (4) } \\
\hline & & $d y / d x$ & S.D. & $d y / d x$ & S.D. & $d y / d x$ & S.D. & $d y / d x$ & S.D. \\
\hline \multirow{4}{*}{ Human capital } & Postgraduate & $0.165 * *$ & 0.064 & $0.138 * *$ & 0.066 & 0.075 & 0.070 & 0.067 & 0.072 \\
\hline & Experience in management & $-0.188 * * *$ & 0.067 & $-0.194 * * *$ & 0.069 & $-0.202 * * *$ & 0.071 & $-0.200 * * *$ & 0.072 \\
\hline & Experience in sector & 0.105 & 0.081 & 0.083 & 0.085 & 0.105 & 0.087 & 0.109 & 0.088 \\
\hline & Experience as a founder & 0.035 & 0.066 & 0.064 & 0.068 & 0.090 & 0.072 & 0.116 & 0.072 \\
\hline \multirow{3}{*}{ Personal aspirations } & Orientation to growth & & & $0.222 * * *$ & 0.073 & $0.216 * * *$ & 0.075 & $0.246 * * *$ & 0.076 \\
\hline & Personal satisfaction & & & 0.074 & 0.046 & $0.079 *$ & 0.045 & $0.095 * *$ & 0.045 \\
\hline & Recognition & & & $-0.060 *$ & 0.032 & $-0.081 * *$ & 0.032 & $-0.093 * * *$ & 0.033 \\
\hline \multirow{3}{*}{$\begin{array}{l}\text { Link to public } \\
\text { system of R\&D }\end{array}$} & TTO support & & & & & $0.308 * * *$ & 0.077 & $0.312 * * *$ & 0.077 \\
\hline & Location in technology park & & & & & -0.010 & 0.073 & 0.016 & 0.074 \\
\hline & Academic entrepreneurs & & & & & $0.153 * *$ & 0.073 & $0.141 *$ & 0.075 \\
\hline Planning & Previous interaction with market & & & & & & & $-0.238 * * *$ & 0.088 \\
\hline Manufacturer & & 0.030 & 0.085 & 0.028 & 0.089 & 0.044 & 0.091 & 0.042 & 0.089 \\
\hline Created with > $10 \mathrm{em}$ & ployees & $-0.275 * * *$ & 0.102 & $-0.274 * * *$ & 0.105 & $-0.236 * *$ & 0.112 & $-0.226 *$ & 0.117 \\
\hline Madrid-Catalonia-Bas & que Country & $0.319 * * *$ & 0.061 & $0.292 * * *$ & 0.063 & $0.344 * * *$ & 0.064 & $0.345 * * *$ & 0.065 \\
\hline \multirow[t]{3}{*}{ Wald Test [p-value]: } & Human capital & \multicolumn{2}{|c|}{$[0.003]$} & \multicolumn{2}{|c|}{ [0.012] } & \multicolumn{2}{|c|}{ [0.031] } & \multicolumn{2}{|c|}{ [0.023] } \\
\hline & Personal Aspirations & & & \multirow{2}{*}{\multicolumn{2}{|c|}{ [0.003] }} & \multicolumn{2}{|c|}{$[0.001]$} & \multicolumn{2}{|c|}{$[0.000]$} \\
\hline & Link to public system of R\&D & & & & & \multicolumn{2}{|c|}{$[0.000]$} & \multicolumn{2}{|c|}{$[0.000]$} \\
\hline & \multicolumn{2}{|c|}{66.79} & \multicolumn{2}{|l|}{66.42} & \multicolumn{2}{|c|}{70.48} & \multicolumn{2}{|c|}{72.23} \\
\hline \multicolumn{2}{|c|}{ Correct predictions $(1 / 0)$} & \multicolumn{2}{|c|}{$(67.67 / 65.94)$} & \multicolumn{2}{|c|}{$(66.92 / 65.94)$} & \multicolumn{2}{|c|}{$(67.67 / 73.19)$} & \multicolumn{2}{|c|}{$(72.18 / 72.46)$} \\
\hline \multirow{2}{*}{\multicolumn{2}{|c|}{ Adjusted R2 }} & \multicolumn{2}{|c|}{0.137} & \multicolumn{2}{|c|}{0.173} & \multicolumn{2}{|c|}{0.233} & \multicolumn{2}{|c|}{0.251} \\
\hline Number of observations & & 271 & & 271 & & 271 & & 27 & \\
\hline
\end{tabular}

Note: The marginal effects $(d y / d x)$ are evaluated at the sample mean. For the dichotomous variables, the marginal effect corresponds to the change from 0 to 1 . S.D.

indicates standard deviation. ${ }^{*} p<0.05 ;{ }^{* *} p<0.01 ;{ }^{* * *} p<0.001$. Wald Test [p-value] indicates the $p$-value of the Wald test for joint significance for the block indicated. 
Table 4 (cont.): Probability of participating in the NEOTEC program. Probit Model

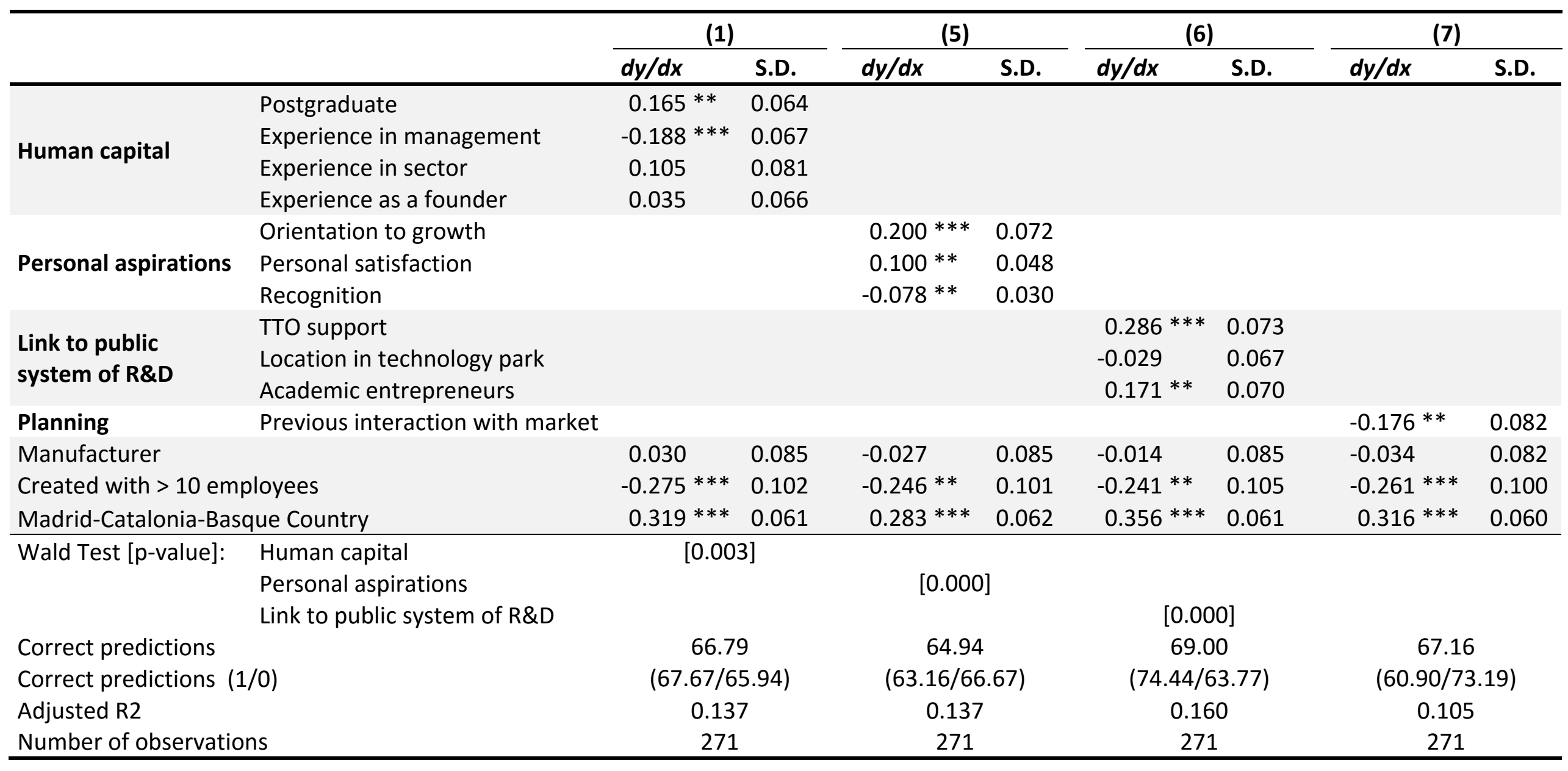

Note: The marginal effects $(d y / d x)$ are evaluated at the sample mean. For the dichotomous variables, the marginal effect corresponds to the change from 0 to 1 . S.D.

indicates standard deviation. ${ }^{*} p<0.05 ;^{* *} p<0.01 ;{ }^{* * *} p<0.001$. Wald Test [p-value] indicates the $\mathrm{p}$-value of the Wald test for joint significance for the block indicated. 
Table 5: Probability of obtaining public or private external financing. Bivariate Probit Model

\begin{tabular}{|c|c|c|c|c|c|c|c|}
\hline & \multirow[b]{2}{*}{ Variables } & \multicolumn{3}{|c|}{ NEOTEC public financing } & \multicolumn{3}{|c|}{ External private financing } \\
\hline & & Coeffic & cient & S.D. & Coefficie & & S.D. \\
\hline \multirow{4}{*}{ Human capital } & Postgraduate & 0.150 & & $(0.174)$ & -0.142 & & $(0.172)$ \\
\hline & Experience in management & -0.442 & $* *$ & $(0.186)$ & 0.004 & & $(0.179)$ \\
\hline & Experience in sector & 0.286 & & $(0.221)$ & -0.377 & $*$ & $(0.215)$ \\
\hline & Experience as a founder & 0.319 & $*$ & $(0.178)$ & -0.051 & & $(0.172)$ \\
\hline \multirow{3}{*}{ Personal aspirations } & Orientation to growth & 0.638 & $* * *$ & $(0.208)$ & 0.227 & & $(0.192)$ \\
\hline & Personal satisfaction & 0.246 & $* *$ & $(0.118)$ & 0.233 & $* *$ & $(0.111)$ \\
\hline & Recognition & -0.255 & $* * *$ & (0.079) & 0.145 & $*$ & $(0.088)$ \\
\hline \multirow{3}{*}{$\begin{array}{l}\text { Link to public } \\
\text { system of R\&D }\end{array}$} & TTO support & 0.804 & $* * *$ & (0.214) & 0.406 & $*$ & $(0.227)$ \\
\hline & Location in technology park & 0.019 & & $(0.181)$ & 0.051 & & $(0.172)$ \\
\hline & Academic entrepreneurs & 0.393 & $* *$ & $(0.186)$ & 0.314 & $*$ & $(0.190)$ \\
\hline Planning & Previous interaction with market & -0.548 & $* *$ & $(0.250)$ & -0.229 & & $(0.221)$ \\
\hline \multicolumn{2}{|l|}{ Manufacturer } & 0.080 & & $(0.218)$ & 0.246 & & $(0.227)$ \\
\hline \multicolumn{2}{|c|}{ Created with $>10$ employees } & -0.585 & $*$ & $(0.331)$ & 0.167 & & $(0.293)$ \\
\hline \multicolumn{2}{|c|}{ Madrid-Catalonia-Basque Country } & 0.805 & $* * *$ & $(0.176)$ & -0.375 & $* *$ & $(0.174)$ \\
\hline \multicolumn{2}{|l|}{ Rho } & \multicolumn{6}{|c|}{$0.023(0.111)$} \\
\hline \multicolumn{2}{|l|}{ Log-likelihood } & \multicolumn{6}{|c|}{-305.909} \\
\hline \multicolumn{2}{|c|}{ Number of observations } & \multicolumn{6}{|c|}{271} \\
\hline
\end{tabular}

Note: S.D. indicates standard deviation. ${ }^{*} p<0.05 ;{ }^{* *} p<0.01 ;{ }^{* * *} p<0.001$. 